\title{
Preparation and characterization of halogen-free flame retardant MCA core-shell microcapsules coated with melamine or acrylic acid resin
}

\author{
Xiaoyi Zhang ${ }^{1)}$ (ORCID ID: 0000-0003-4047-5046), Zheng Gu ${ }^{1), 2), *)}$ (0000-0001-9521-2863), Jinyong Sui ${ }^{1)}$ (0000-0002-4232-3540), \\ Zhenxu Li ${ }^{1)}$ (0000-0003-3998-9090), Lining Song ${ }^{1)}$ (0000-0002-5671-4745), Lina Yang') (0000-0002-5518-050X), \\ Ning Wang' ${ }^{1)}(0000-0002-2509-3886)$, Jie Zhao ${ }^{1)}(0000-0002-6754-3785)$
}

DOI: dx.doi.org/10.14314/polimery.2021.4.4

\begin{abstract}
The resin melamine cyanurate (MCA) core-shell microcapsules were prepared by surface coating modification of halogen-free flame retardant MCA using melamine resin and acrylic resin as wall materials. The influence of different wall materials on the coating effect of halogen-free flame retardant MCA was studied by SEM, particle size analysis, IR, and DSC and TGA methods. The results showed that the melamine resin had a high degree of polymerization and decomposed at about $160^{\circ}$, which had a surface modification effect on MCA and did not affect its flame retardant performance. The surface coating rate of poly(methyl methacrylate) PMMA-MCA core-shell microcapsules was about $80 \%$. After adding acrylic acid (AA) as the second monomer the coating effect was significantly improved and the thermal decomposition temperature of the wall material of the microcapsule was reduced.
\end{abstract}

Keywords: melamine cyanurate, resin, microcapsule, modified.

\section{Otrzymywanie i charakterystyka bezhalogenowych, uniepalniających mi- krokapsułek MCA typu rdzeń-otoczka powlekanych żywicą melaminową lub akrylową}

Streszczenie: Mikrokapsułki typu rdzeń-otoczka otrzymywano, modyfikując powierzchnię bezhalogenowego, opóźniającego palenie cyjanuranu melaminy (MCA) przy użyciu żywicy melaminowej lub akrylowej. Wpływ rodzaju użytego materiału na efekt powlekania powierzchni mikrokapsułki MCA badano metodami SEM, analizy wielkości cząstek, IR oraz DSC i TGA. Żywica melaminowa wykazywała wysoki stopień polimeryzacji i ulegała rozkładowi w temperaturze ok. $160^{\circ}$, co miało wpływ na efekt modyfikacji powierzchni MCA, ale nie zmieniało jego właściwości uniepalniających. Stopień powlekania powierzchni mikrokapsułki MCA typu rdzeń-otoczka żywicą (PMMA) poli(metakrylan metylu) wynosił ok. 80\%. Po dodaniu kwasu akrylowego (AA) jako drugiego monomeru, efekt powlekania znacznie się poprawił, a temperatura rozkładu termicznego materiału ścianki mikrokapsułki się obniżyła.

Słowa kluczowe: cyjanuran melaminy, żywica, mikrokapsułka, modyfikacja.

Flame retardant is a kind of functional auxiliary that can make inflammable polymers obtain non-inflammable properties. Its development, research and application have been widely concerned. It is a very important auxiliary in polymer materials [1-3]. Melamine cyanurate (MCA) is a new nitrogenous additive flame retardant, an environment-friendly halogen-free with high efficiency, so it has been widely used in the field of flame retar-

1) College of Chemistry and Chemical Engineering, Qingdao University Shandong, China 266071.

2) Weihai Innovation Institute, Qingdao University Shandong, China 264200.

*) Author for correspondence: guzheng596@163.com dation [4-7]. However, due to the lack of active groups on the surface of traditional MCA, the compatibility between MCA particles and various polymer materials is poor, and certain agglomeration often occurs during use, thus reducing its flame retardant effect. Therefore, MCA needs to be surface-treated before it can be applied more effectively and widely [8].

In recent years, the modification of flame retardant surface by microencapsulation technology has become an effective method $[9,10]$. Han et al. [11] modified ammonium polyphosphate (APP) by surface treatment using melamine and formaldehyde as raw materials, and obtained microencapsulated ammonium polyphosphate MCAPP to improve the defects of APP's easy moisture 
absorption and poor compatibility with high density polyethylene (HDPE) in its flame retardant modification system. Cheng et al. [12] successfully synthesized ammonium polyphosphate microencapsulated by polyurea (POAPP) with ammonium polyphosphate as core and polyurea as shell by interfacial polymerization and applied it to rigid polyurethane foam (RPUF) to improve its flame retardant and mechanical properties. Zhang et al. [13] using ammonium phosphomolybdate trihydrate as raw material, synthesized high-efficiency flame retardant aluminum phosphate (ALP) microcapsule and applied it to polyurethane foam, making its limit oxygen index value reach $28.5 \%$. Tao et al. [14] used aluminum diethyl diphosphate (ADP) and ammonium polyphosphate (APP) as core materials and coated them with epoxy resin to prepare two types of microcapsules. Then they were compounded and added to high-density polyethylene (HDPE) to improve the flame retardant effect. Salaün et al. [15] used the co-polymerization of melamine and formaldehyde as the wall material, coated diammonium phosphate and 1,6-hexamethylene adipate respectively through in situ polymerization, and prepared two types of microcapsules. Then they were fused and mixed with polypropylene matrix to improve their mechanical and flame retardant properties.

After surface treatment and chemical coating, using melamine resin and acrylic resin as the capsule wall cladding material, with halogen-free flame retardant melamine cyanuric acid salt (MCA) as core material, the melamine resin-MCA core-shell microcapsules and acrylic resin-MCA core-shell microcapsules were prepared, and a number of analytical tests were carried out.

\section{EXPERIMENTAL PART}

\section{Materials}

Melamine cyanurate MCA, industrial grade, Shandong Shouguang Weidong Chemical Co., LTD., $\gamma$-methacryloxypropyltrimethoxysilane $\mathrm{KH}-570$, chemically pure, Nanjing Youpu Chemical Co., Ltd., methyl methacrylate MMA, chemical purity, Sinopharm Group Chemical Reagent Co., LTD., ammonium persulfate, analytically pure, Sinopharm Group Chemical Reagent Co., LTD., melamine, chemical pure, Sinopharm Group Chemical Reagent Co., LTD., 37\% formaldehyde solution, chemical pure, Sinopharynx Group Chemical Reagent Co., LTD., anhydrous ethanol, analytically pure, Yantai Sanhe Chemical Reagent Co., LTD., self-made deionized water.

\section{Preparation of melamine-MCA core-shell microcapsules}

\section{Preparation of core material system}

An appropriate amount of MCA was weighted using electronic balance(type YP10002, Shanghai Hengji
Scientific Instrument Co., Ltd.) and put into a three-point flask, deionized water and $1 \%$ compound emulsifier [poly(vinyl alcohol), sodium dodecyl benzene sulfonate] were added, JRJ300-SH digital display shear emulsifying mixer (Shanghai Specimen Model Factory) was used, the system temperature was set at $60^{\circ} \mathrm{C}$, the stirring speed was $800 \mathrm{rpm}$, and the time of reaction was $2 \mathrm{~h}$.

\section{Preparation of melamine resin prepolymers}

The formaldehyde solution was mixed with melamine, and the DF-101S heat-collecting constant temperature magnetic agitator (Zhengzhou Keda Mechanical Instrument Equipment Co., Ltd.) was used to heat the system. The temperature of the system was set at $70^{\circ} \mathrm{C}$, the stirring speed was $600 \mathrm{rpm}$, the $\mathrm{pH}$ of the system was 8.5 (adjusted with $10 \% \mathrm{Na}_{2} \mathrm{CO}_{3}$ solution), and the reaction continued for $15 \mathrm{~min}$ after the solution was clarified.

\section{Preparation of melamine resin-MCA microcapsules}

Acetic acid solution was added to the core material system, and its $\mathrm{pH}$ value was adjusted to 4 . Then, the prepared melamine resin prepolymer was added. The temperature of the system was set at $60^{\circ} \mathrm{C}$, the stirring speed was $600 \mathrm{rpm}$, and the sealing reaction time was $2 \mathrm{~h}$. After the reaction, the product was washed, dried and ground to obtain the microcapsules.

\section{Preparation of acrylic resin-MCA core-shell microcapsules}

\section{Surface modification of MCA}

MCA was placed in a beaker, anhydrous ethanol was added, and BT-50 ultrasonic disperser (Dandong Baxter Instrument Co., Ltd.) was used for $30 \mathrm{~min}$ to make the dispersion uniform. Then the solution was transferred to a three-necked flask. After the system temperature rose to $70^{\circ} \mathrm{C}$, the silane coupling agent $\mathrm{KH}-570$ was dropped and reflux reaction was conducted for $1 \mathrm{~h}$. After the reaction, the MCA turbid solution was placed in a 101-3A electric heating blast drying oven (Tianjin Tester Instrument Co., Ltd.), dried at $65^{\circ} \mathrm{C}$ for $3 \mathrm{~h}$, and then ground to obtain the surface modified MCA.

\section{Preparation of MCA core-shell microcapsules coated with acrylic resin}

The modified MCA was placed in a beaker, deionized water was added, stirred at $3000 \mathrm{rpm}$ rotation speed for 5 min to make it evenly dispersed, then the turbidity liquid was transferred to a three-necked flask, heated to $70^{\circ} \mathrm{C}$, monomer MMA was added slowly, and then ammonium persulfate was added to initiate polymerization. In $\mathrm{N}_{2}$ atmosphere, the reaction was sealed for $2.5 \mathrm{~h}$. After the reaction, the product was filtered with SHZ-D (III) circulat- 
ing water vacuum pump (Zhengzhou Keda Mechanical Instrument Co., Ltd.) and washed with anhydrous ethanol and deionized water, dried in the oven and ground, and the microcapsules PMMA-MCA obtained.

P(MMA-AA)-MCA microcapsules were prepared by changing the wall material to MMA and AA with a mass ratio of $10: 1$. Other experimental conditions were unchanged.

\section{Methods of testing}

\section{Scanning electron microscopy (SEM)}

The prepared microcapsules were sprayed with gold by surface vacuum sputtering, and the surface morphology of the particles was observed using Zeiss SIGMA 500/VP (Carl Zeiss, Germany) high resolution field emission scanning electron microscope.

\section{Differential scanning calorimetry (DSC)}

HCT-1 comprehensive thermal analyzer (Beijing Yongjiu Scientific Instrument Factory) was used to detect the samples. The test temperature was raised to $350^{\circ} \mathrm{C}$ at a rate of $20^{\circ} \mathrm{C} / \mathrm{min}$ starting from room temperature, under nitrogen atmosphere, and the airflow was $50 \mathrm{~cm}^{3} / \mathrm{min}$.

\section{Thermogravimetric analysis (TGA)}

HCT-1 comprehensive thermal analyzer (Beijing Yongjiu Scientific Instrument Factory) was used to observe the decline of sample quality with the increase of system temperature. The test temperature started from room temperature and rose to $500^{\circ} \mathrm{C}$ at a rate of $10^{\circ} \mathrm{C} / \mathrm{min}$.

\section{Particle size distribution test (PSD)}

The samples were dispersed with deionized water. After ultrasonic dispersion, the samples were put into a sampler and their particle size distribution was measured with a BT-9300H laser particle size distribution analyzer (Dandong Baite Instrument Co., LTD.).

\section{Fourier-transform infrared spectroscopy (FT-IR)}

The chemical structures of the samples were analyzed by means of iS50 Fourier transform infrared spectrometer (Nicolet). It was scanned 32 times at a wavelength of $4000 \sim 400 \mathrm{~cm}^{-1}$.

\section{RESULTS AND DISCUSSION}

\section{Melamine resin-MCA core-shell microcapsules}

\section{SEM analysis}

An important factor in the preparation of melamine resin-MCA core-shell microcapsules is the place where the wall monomer polymerized. Obviously, only the polymerization of the wall monomer on the surface of the MCA particle can ensure the coating effect. However, due to the surface inertia of the MCA, direct addition of
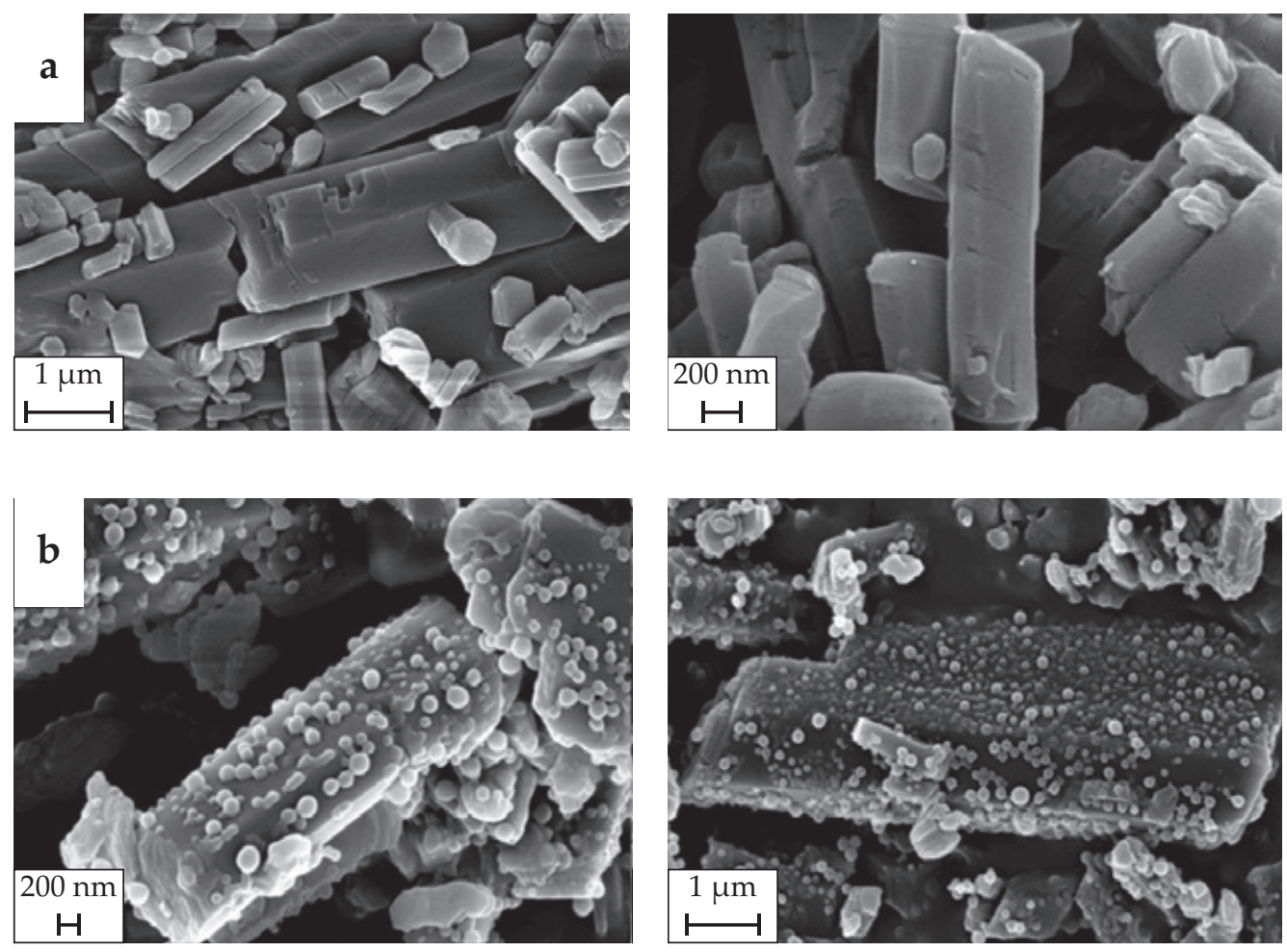

Fig. 1. SEM microphotographs of a) original MCA, b) melamine resin-MCA core-shell microcapsules 
wall monomer into the reaction system cannot achieve cladding. Therefore, grafting treatment on the surface of MCA is required first to improve the surface activity of MCA and increase its ability to absorb wall monomer. In this test, emulsifier is first used to modify the surface of MCA. When wall monomer is added to the reaction system, according to the principle of "similar phase dissolution", the wall monomer will give priority to deposition on the surface of MCA after surface modification.

Figure 1 shows the scanning electron microscope (SEM) images of original MCA (Fig. 1a) and melamine resin-MCA core-shell microcapsule (Fig. 1b). The original MCA has a smooth surface and is mainly a bar structure with regular shape and different lengths, with diameter between $0.2-1.0 \mu \mathrm{m}$. In comparison, the surface of MCA microcapsule has more globular melamine resin, and the coating rate is about $50-60 \%$. At the same time, the coating effect of melamine resin on the surface of MCA particles is different: the agglomeration of melamine resin on the smooth surface is bigger, while the coating effect on the fractured surface is relatively better. This is caused by the difference in the effect of emulsifier on the MCA surface during the preparation of the core material system. Because of the many folds at the fractured surface of MCA particles, the specific surface area is bigger than that on the smooth surface. Therefore, when adding melamine resin prepolymer for polymerization reaction, polymerization cladding at the fractured surface is preferred.

\section{Particle size test analysis}

Figure 2 shows the size test results of the original MCA and the melamine resin-MCA core-shell microcapsules. The size distribution range of the original MCA is relatively wide, most of them are distributed between

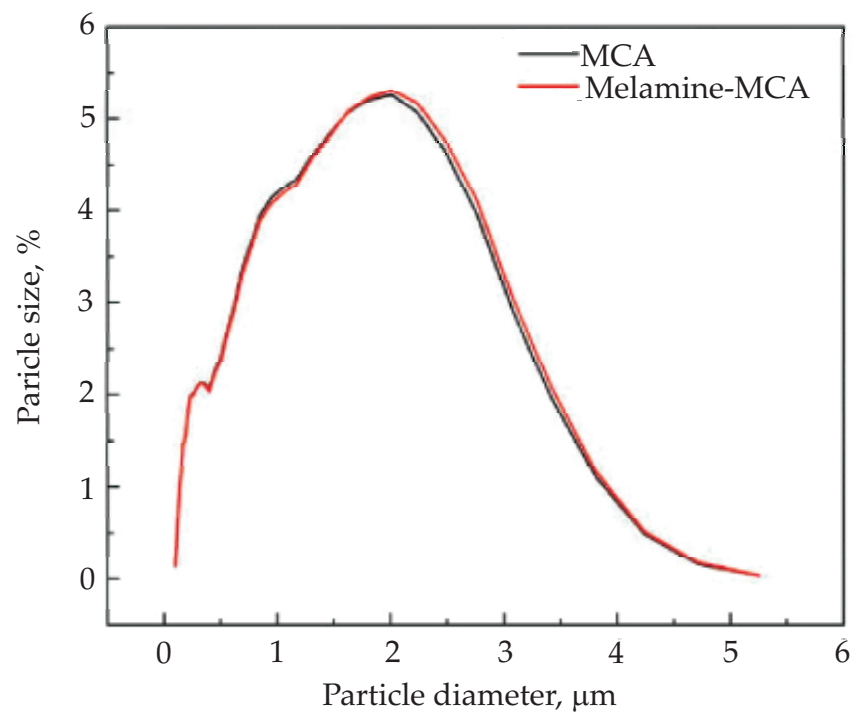

Fig. 2. Size test results of: original MCA and melamine resinMCA core-shell microcapsules
$0.25 \mu \mathrm{m}$ and $2.80 \mu \mathrm{m}$, and the median size D50 is $1.16 \mu \mathrm{m}$. After coating with melamine resin, D50 was $1.18 \mu \mathrm{m}$, slightly increased than the original MCA, indicating that melamine resin successfully coated on the surface of MCA particles, but the coating effect was not particularly good. At the same time, there was no significant effect on the particle size of melamine resin spheres in the solution, indicating that the degree of polymerization of melamine resin was higher.

\section{DSC and TGA thermal analysis}

Figure 3 shows the TGA curves of melamine resin-MCA core-shell microcapsules. The thermal degradation process of microcapsules is divided into three stages. When the temperature was below $167^{\circ} \mathrm{C}$, the sample mass did not change significantly, indicating that no significant thermal degradation occurred in the microcapsules at this stage. When the temperature reached $167^{\circ} \mathrm{C}$, the mass of the sample began to decline slightly, which was the effect of the thermal degradation of the wall material melamine resin and the decomposition of formaldehyde gas was released. When the temperature reached $343^{\circ} \mathrm{C}$, the sample quality declined rapidly, and at this stage it was the degradation process of MCA. After reaching the temperature of $406^{\circ} \mathrm{C}$, the weight of the sample drops to half of its initial value. When the temperature reached $506^{\circ} \mathrm{C}$, the sample mass did not decline, indicating that the decomposition had been completed and the residual amount of the sample was about 3\%.

Figure 4 shows the thermal fusion analysis curve of melamine resin-MCA core-shell microcapsule. The initial endothermic temperature of the melamine resin-MCA core-shell microcapsule is about $325^{\circ} \mathrm{C}$ and the peak temperature is $421^{\circ} \mathrm{C}$. At the same time, wall material melamine res-

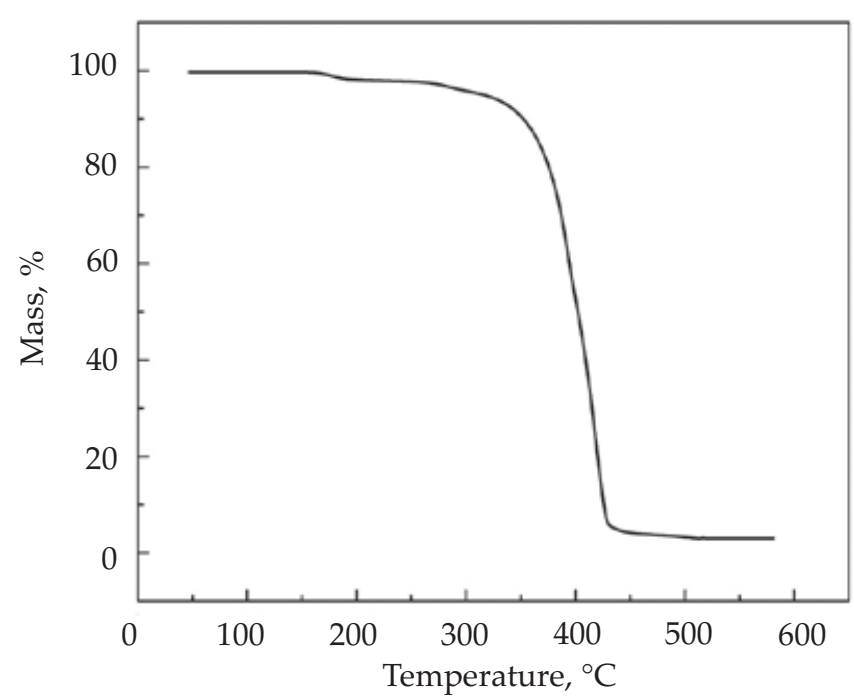

Fig. 3. TGA curve of melamine-MCA core-shell microcapsules 


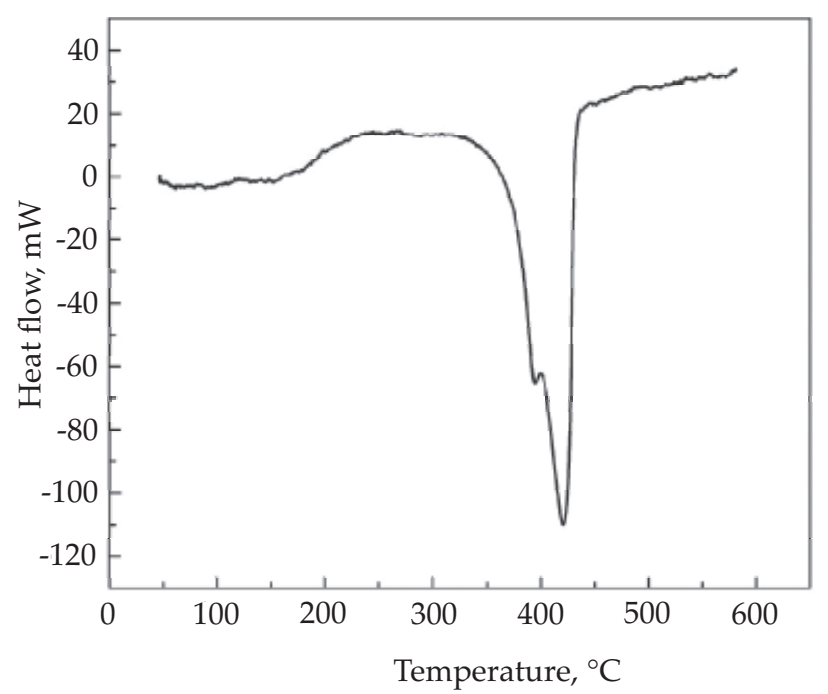

Fig. 4. DSC curve of melamine-MCA core-shell microcapsules

in has the effect of thermal insulation protection, making the peak initial temperature of MCA microcapsule slightly higher than the peak initial temperature of the original MCA.

\section{Acrylic resin-MCA core-shell microcapsules}

\section{SEM analysis}

Figure 5 shows the microphotographs SEM of the PMMA-MCA core-shell microcapsules. The comparison with the SEM microphotographs of original MCA shows that the surface morphology of MCA particles changes significantly after being coated with acrylic resin. Figure 5a is SEM images of PMMA-MCA core-shell microcapsules, coated with poly(methyl methacrylate) (PMMA) as wall materials. Thick layer of PMMA on the surface of MCA particles can be observed. However, the surface is not completely covered, and the covering rate is about $80 \%$. It is mainly because of the fact that in the process of polymerization coating, MMA cannot be completely deposited on the MCA surface. This prevents the polymer PMMA from completely coating of the MCA. Figure $5 b$ shows the P(MMA-AA)-MCA core-shell microcapsules formed by copolymerization of MMA and acrylic acid (AA). Through comparison, it can be seen that the microcapsules generated by copolymerization have basically achieved complete coating, but there are certain folds and agglomerations on the surface, mainly because of the fact that during surface grafting modification of MCA particles by using $\mathrm{KH}-570$, the adhesion amount of KH-570 on the surface of MCA particles was different, resulting in different deposition amount of PMMA generated by polymerization on the surface of MCA. Moreover, PMMA generated in the later stage of polymerization was not affected by $\mathrm{KH}-570$, and the density of polymer generated before and after was different, thus forming a fold. In addition, the nonuniformity of the copolymerization of MMA and AA will also result in different polymer densities, causing the generation of wrinkles.
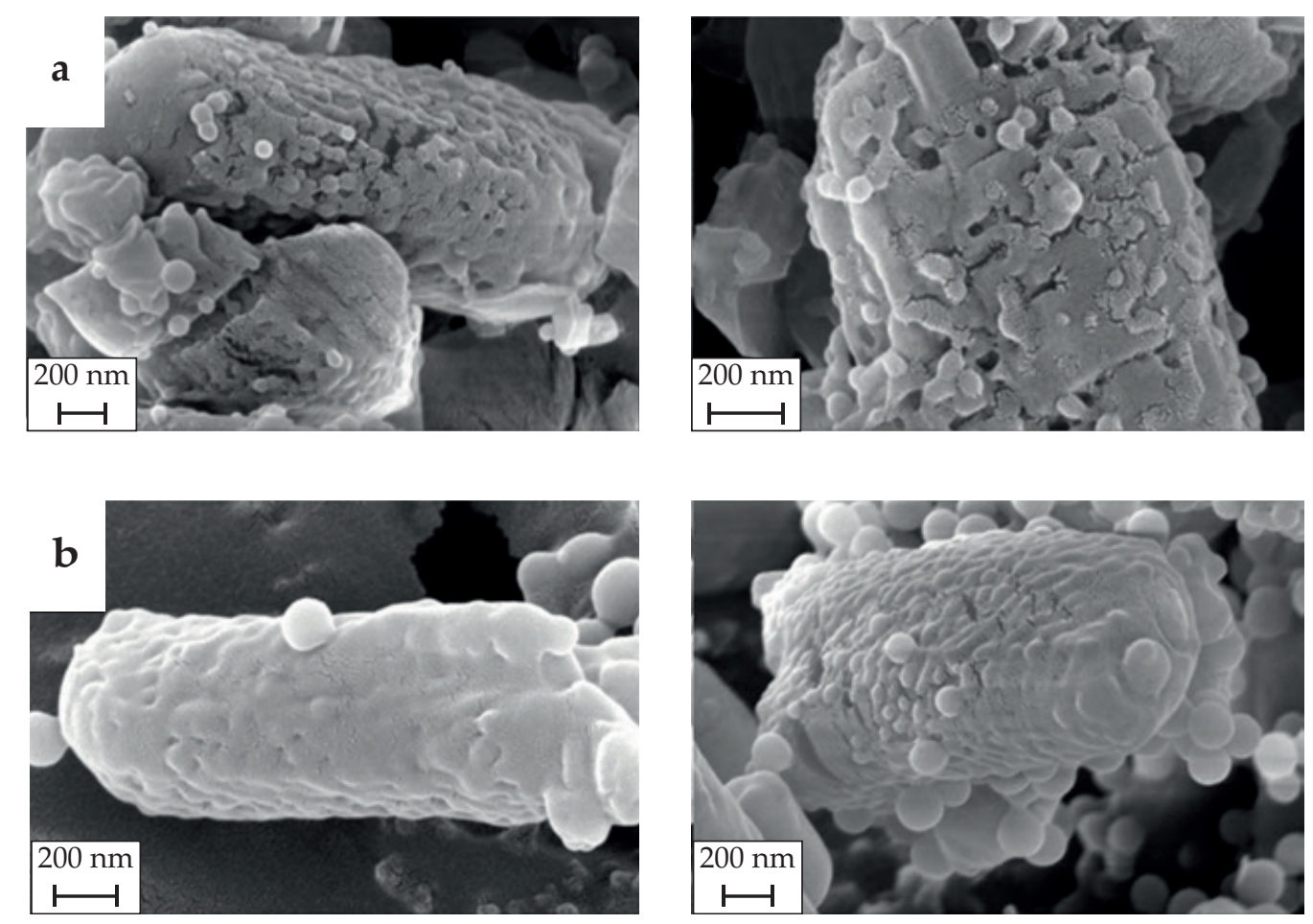

Fig. 5. SEM microphotographs of: a) PMMA-MCA core-shell microcapsules, b) P(MMA-AA)-MCA core-shell microcapsules 


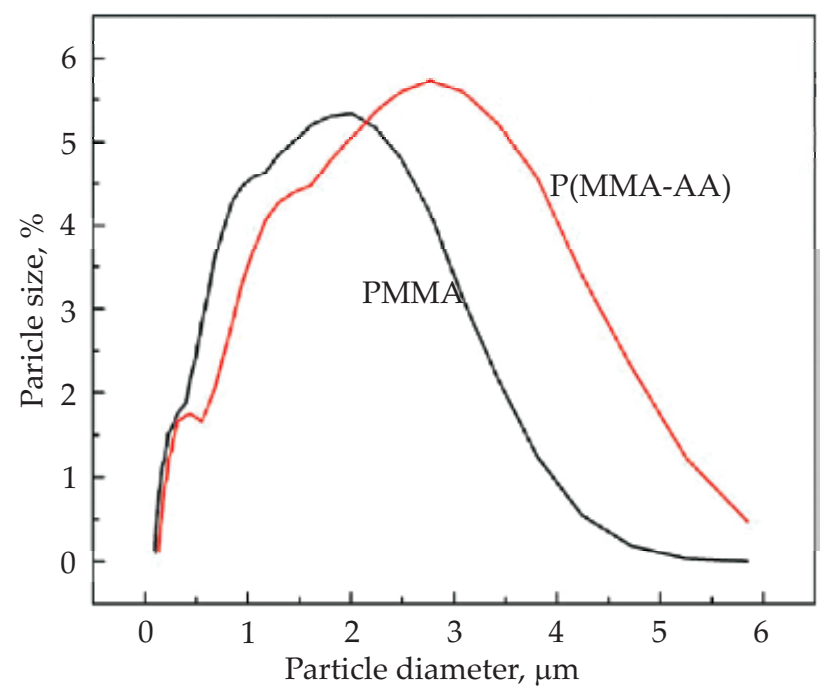

Fig. 6. Particle size test results of PMMA-MCA and P(MMA-AA) MCA core-shell microcapsules

\section{Particle size test analysis}

Figure 6 shows the particle size test results of PMMA-MCA core-shell microcapsule and P(MMA-AA)-MCA core-shell microcapsule. The results showed that the D50 of PMMA-MCA core-shell microcapsule was $1.2 \mu \mathrm{m}$, higher than the original MCA, which proved the successful preparation of PMMA-MCA core-shell microcapsules. After the addition of AA as the second comonomer, the particle size of P(MMA-AA)-MCA coreshell microcapsule was significantly increased, with D50 reaching $1.3 \mu \mathrm{m}$, which was $0.1 \mu \mathrm{m}$ higher than the average particle size of the original MCA, indicating that the coating thickness of P(MMA-AA) copolymer on the MCA surface was increased and the coating effect was better.

\section{FT-IR analysis}

Figure 7 shows the infrared spectrum analysis of original MCA, PMMA-MCA and P(MMA-AA)-MCA core-shell microcapsules. It can be seen that there is an absorption peak between $3000 \mathrm{~cm}^{-1}$ and $2800 \mathrm{~cm}^{-1}$, corresponding to the $-\mathrm{CH}_{3}$ group of MCA. The infrared curve of MCA showed a stretching vibration peak associated with $\mathrm{N}-\mathrm{H}$ at $3370 \mathrm{~cm}^{-1}$, and the peak intensity was relatively strong. However, the intensity of this peak was significantly reduced in the case of the microcapsules coated with acrylic resin, indicating that the surface of MCA particles were successfully coated with PMMA and $\mathrm{P}(\mathrm{MMA}-\mathrm{AA})$. In addition, within the range of $2000 \mathrm{~cm}^{-1}$ to $1200 \mathrm{~cm}^{-1}$, there were multiple absorption peaks corresponding to the stretching vibration peaks of $\mathrm{C}=\mathrm{O}$ and $\mathrm{C}=\mathrm{N}$, respectively. There was no absorption peak of $\mathrm{C}=\mathrm{C}$ near $1600 \mathrm{~cm}^{-1}$, indicating that the polymerization reaction between monomers was complete.

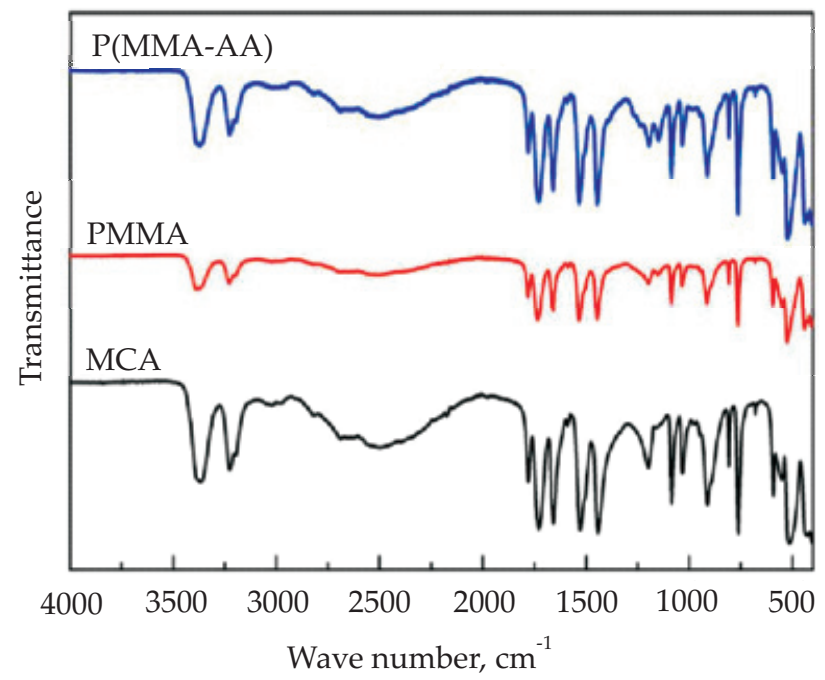

Fig. 7. FT-IR spectrum of original MCA, PMMA-MCA and P(MMA-AA)-MCA core-shell microcapsules

\section{TGA and DSC analysis}

Figure 8 shows the thermogravimetric analysis curves of PMMA-MCA and P(MMA-AA)-MCA core-shell microcapsules. It can be seen that the thermal degradation process of acrylic resin-MCA core-shell microcapsules is also divided into three stages. For PMMA-MCA core-shell microcapsules, when the temperature was lower than $283^{\circ} \mathrm{C}$, the sample mass did not change significantly, indicating that no significant thermal degradation occurred at this stage. When the temperature reached $283^{\circ} \mathrm{C}$, the degradation process of PMMA started, and the mass loss rate was about $0.5 \%$. After the temperature reached $301^{\circ} \mathrm{C}$, the sample mass declined rapidly, and this stage was the thermal decomposition of MCA. In the temperature of $444^{\circ} \mathrm{C}$, the sample mass did not decline, indicating that the sample

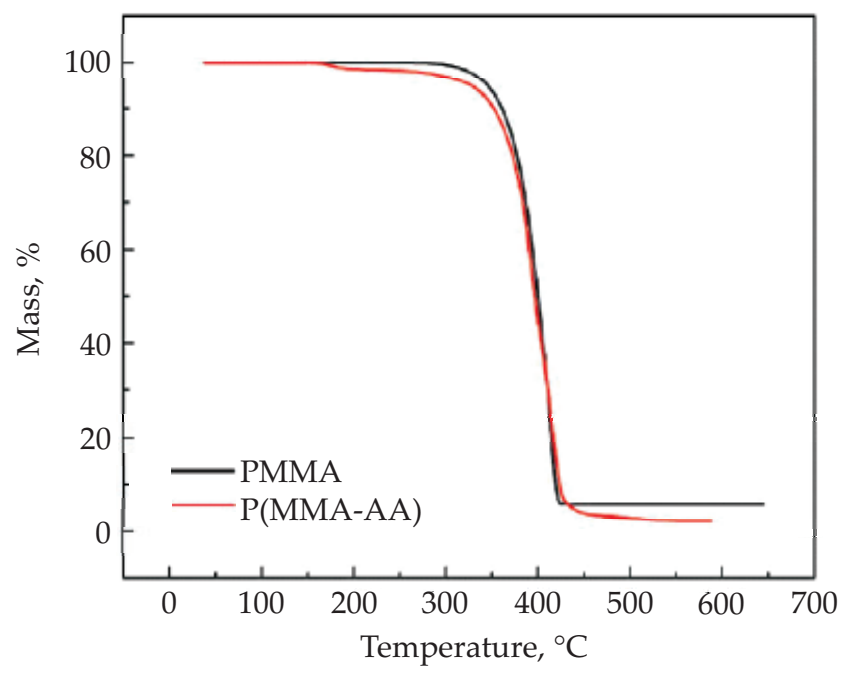

Fig. 8. TGA curves of PMMA-MCA and P(MMA-AA)-MCA core-shell microcapsules 
had been completely decomposed and the final residual rate was about $6 \%$. The thermal degradation process of P(MMA-AA)-MCA core-shell microcapsules was also divided into three stages, but compared with PMMA-MCA core-shell microcapsules, the initial temperature of thermal degradation was significantly changed. The thermal degradation process of $\mathrm{P}(\mathrm{MMA}-\mathrm{AA})$ wall material mainly occurred from $166^{\circ} \mathrm{C}$ to $199^{\circ} \mathrm{C}$, and the mass loss rate was about $2 \%$, which was significantly higher than $0.5 \%$ of PMMA wall material. Meanwhile, the initial temperature of thermal degradation was about $118^{\circ} \mathrm{C}$, lower than that of PMMA. The thermal degradation process of core material MCA of the two microcapsules was very similar without significant difference. The results show that the addition of AA as the second comonomer not only improves the coating effect, but also reduces the thermal stability of the wall material, making it more prone to thermal degradation, which is enhancing of the flame retardant property of MCA.

Figure 9 shows the DSC curves of PMMA-MCA and P(MMA-AA)-MCA core-shell microcapsules. The strong melting temperature peak can be observed about $417^{\circ} \mathrm{C}$ for both PMMA-MCA and P(MMA-AA)-MCA core-shell microcapsules. The melting temperature of PMMA-MCA core-shell microcapsules was slightly higher than of MCA due to the thermal insulation protection of the acrylic resin. Moreover, a weaker peak about $390^{\circ} \mathrm{C}$ was observed for P(MMA-AA)-MCA. This is mainly because AA was added to the system, in the process of polymerization, MMA and AA will have a copolymerization reaction to form $\mathrm{P}(\mathrm{MMA}-\mathrm{AA})$ copolymer, which will be coating on the surface of MCA particles, and the phase transition temperature of $\mathrm{P}(\mathrm{MMA}-\mathrm{AA})$ copolymer is low, which reduces the initial melting temperature of $\mathrm{P}(\mathrm{MMA}-$ -AA)-MCA core-shell microcapsules.

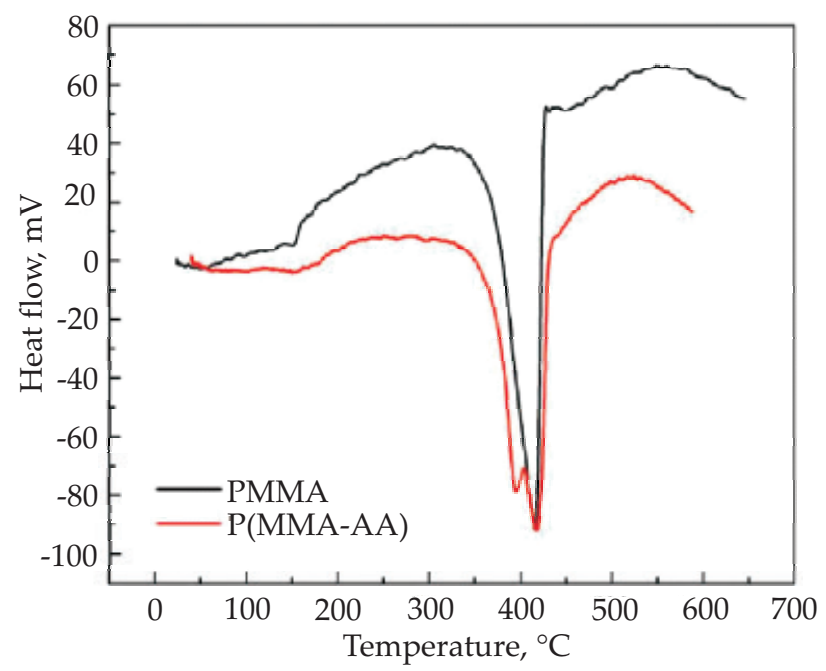

Fig. 9. DSC curves of PMMA-MCA and P(MMA-AA)-MCA core-shell microcapsules

\section{CONCLUSION}

The core material MCA was surface treated with emulsifier, and then the MCA was chemically coated with melamine resin and acrylic resin as wall materials through the polymerization reaction. Finally, the melamine resinMCA core-shell microcapsules, PMMA-MCA core-shell microcapsules and P(MMA-AA)-MCA core-shell microcapsules were prepared. The results show that:

- Emulsifier has a great influence on the coating effect of the resin for the surface treatment of MCA. The coating effect on the rough surface is better then on the smooth surface.

- Melamine resin has a high degree of polymerization and starts to decompose at about $160^{\circ} \mathrm{C}$, to release the MCA core material in the microcapsule and make it play a flame retardant role.

- When PMMA was used as a single wall material, the coating rate of MCA particle surface was about $80 \%$. However, when P(MMA-AA) was used, the coating rate was significantly increased, and the coat thickness was also significantly increased. Meanwhile, the addition of AA reduced the thermal decomposition temperature of the wall material of the microcapsule, which was enhancing the flame retardant property of MCA.

\section{REFERENCE}

[1] Liu C.: Chemical Engineering Design Communication 2020, 46 (10), 24.

doi: CNKI: SUN: WGTX.0.2020-10-016

[2] Cheng X.B.: Synthetic Resins and Plastics 2019, 6, 91. doi: CNKI: SUN: HCSZ.0.2019-06-025

[3] Vahidi G., Bajwa D.S., Shojaeiarani J. et al.: Journal of Applied Polymer Science 2021, 138, 50050.

https://doi.org/10.1002/app.50050

[4] Jiang M.H., Zhou J., Zhang Z. et al.: Engineering Plastics Applications 2020, 48 (08), 135.

doi: CNKI: SUN: ACSN.0.2020-08-028

[5] Yan Y.: "Study on flame retardant property of silicon rubber foam containing MCA microcapsule", $\mathrm{Xi}_{\mathrm{i}}$ 'an University of Science and Technology, 2020.

[6] Mu P., Wang Z., Jiang D.Y. et al.: Fire Science and Technology 2019, 38 (12), 1730. doi: CNKI: SUN: XFKJ.0.2019-12-025

[7] Huang X.Z., Tian Z.J., Zhang D.S. et al.: Polymer Bulletin 2020, 78 (1), 185.

http://dx.doi.org/10.1007/S00289-019-03098-Y

[8] Yang F.X., Yang X.Y., Liu X.H. et al.: Plastics 2018, 6, 107.

doi: CNKI: SUN: SULA.0.2018-06-024

[9] Shi L., Bao Z.H.: Advances in Chemical Industry 2008, 07, 1001.

doi: CNKI: SUN: HGJZ.0.2008-07-009

[10] Qin S.L.: Journal of Popular Science 2020, 22 (05), 47. doi: CNKI: SUN: DZJI.0.2020-05-014

[11] Han H.J., Liang S. J.: Plastics 2020, 49 (05), 24, 33. doi: CNKI: SUN: SULA.0.2020-05-007 
[12] Cheng J., Niu S., Ma D. et al.: Journal of Applied Polymer Science 2020, 137, 49591. https://doi.org/10.1002/app.49591

[13] Zhang B., Liu H., Han J.: Journal of Physics and Chemistry of Solids 2018, 115, 199.

https://doi.org/10.1016/j.jpcs.2017.12.048
[14] Tao S.X., Xia Y.P., Zhang C. et al.: Modern Plastic Processing Applications 2017, 6, 42. doi: CNKI: SUN: XDSL.0.2017-06-015

[15] Salaün F., Lewandowski M., Vroman I. et al.: Polymer Degradation and Stability 2011, 96, 131.

https://doi.org/10.1016/j.polymdegradstab.2010.10.009

\begin{tabular}{|c|c|c|}
\hline $\begin{array}{ll}\text { MODPOL } \\
10=-1\end{array}$ & $\begin{array}{c}\text { Katedra Inżynierii i Technologii Polimerów } \\
\text { Wydział Chemiczny } \\
\text { Politechniki Wrocławskiej } \\
\text { zapraszaja do udziału w }\end{array}$ & 20 \\
\hline 2021 & $\begin{array}{l}\text { XXV Konferencji Naukowej } \\
\text { MODYFIKACJA POLIMERÓW } \\
\text { 6-9 września } 2021 \text { r. }\end{array}$ & $\begin{array}{l}\text { Politechnika } \\
\text { Wrocławska }\end{array}$ \\
\hline \multicolumn{3}{|c|}{ Przewodniczący Konferencji i Komitetu Organizacyjnego: prof. dr hab. inż. Andrzej TROCHIMCZUK } \\
\hline \multicolumn{3}{|c|}{$\begin{array}{l}\text { Konferencja będzie poświęcona multidyscyplinarnym zagadnieniom związanym z polimerami począwszy od } \\
\text { podstawowej syntezy i metodologii do nanoskali i materiałów inspirowanych polimerami naturalnymi }\end{array}$} \\
\hline \multicolumn{3}{|c|}{$\begin{array}{l}\text { Tematyka konferencji: } \\
\text { - } \quad \text { Modyfikacja chemiczna i fizyczna oraz reaktywne przetwarzanie polimerów } \\
\text { - } \text { Synteza, struktura i morfologia polimerów } \\
\text { - } \quad \text { Kompozyty i Nanokompozyty polimerowe } \\
\text { - } \text { Biomateriały i ich zastosowanie biomedyczne } \\
\text { - Materiały kompozytowe reagujące na bodźce } \\
\text { - Tworzywa polimerowe z surowców odnawialnych i wtórnych } \\
\text { - } \quad \text { Biodegradowalne polimery i strategia recyklingu } \\
\text { - Nowe zastosowania oraz metody badań i właściwości polimerów }\end{array}$} \\
\hline Szczegółowe i & wkrótce na stronie internetowej katedry. & \\
\hline & pwr.edu.pl, tel. 661674446 & \\
\hline
\end{tabular}

